\title{
ИННА ЕФРЕМовА
}

\section{Принудительный выкуп земельных участков в публичных интересах как форма прекращения права собственности}

Статья 35 Конституции РФ (Российская Федерация) закрепляет возможность правомерного принудительного отчуждения любого имущества в публичных интересах, в том числе земельных участков, в установленных законом отдельных исключительных случаях и при соблюдении соответствующей процедуры. Эти отношения известны российскому праву сравнительно давно и на современном этапе получили основную правовую регламентацию в Земельном кодексе РФ1, а также в некоторых нормах ГК РФ (Гражданский кодекс Российской Федерации ${ }^{2}$ ), Градостроительного кодекса РФ $\Phi^{3}$ и иных нормативно-правовых актов.

Изъятие земельных участков для государственных и муниципальных нужд неизбежно посягает на частные интересы собственника земли, лишает его возможности свободно и беспрепятственно использовать свое имущество. Поэтому основания такого изъятия являются исключительными и закреплены на законодательном уровне. В соответствии со ст. 49 ЗК РФ (Земельный кодекс Российской Федерации) к ним относятся: выполнение международных обязательств РФ, размещение объектов государственного или муниципального значения при отсутствии других вариантов их возможного размещения и иные обстоятельства в случаях, установленных федеральными законами и законами субъектов РФ.

Процедура изъятия земли в публичных интересах регулируется статьями 279-283 Гражданского кодекса РФ. Решение об изъятии земельного участка путем выкупа может быть принято федеральными органами исполнительной власти, органами исполнительной власти субъекта Российской Федерации или органами местного самоуправления. Собственник должен быть не позднее, чем за год до предстоящего изъятия земельного участка письменно уведомлен об этом органом, принявшим решение об

1 С3 РФ. 2001 № 44, Ст. 4147.

2 СЗ РФ. 1994 № 32, Ст. 3301.

3 СЗ РФ. 2005 № 1 (ч. 1), Ст. 16. 
200 | Adam Mickiewicz University Law Review

изъятии. Выкуп земельного участка до истечения года со дня получения собственником такого уведомления допускается только с согласия собственника. Решение об изъятии подлежит обязательной государственной регистрации.

На следующем этапе возможно два варианта развития взаимоотношений между собственником земельного участка и органом, который инициировал изъятие.

В первом случае, собственник согласен с решением о выкупе земельного участка и действует добровольно. Отношение носит характер частноправовой сделки с недвижимостью, в которой каждая из сторон преследует свои интересы и приходит к взаимовыгодному результату.

Во втором случае, собственник не согласен с решением и условиями выкупа. В такой ситуации государственный орган, принявший решение об изъятии, может обратиться в суд с иском о выкупе земельного участка. Если суд примет решение об отчуждении земельного участка, то оно будет исполнено независимо от воли собственника земли, то есть принудительно.

Интерес представляет природа данного отношения. Несмотря на внешние признаки сделки, принудительный выкуп земли нельзя относить к сугубо рыночному договорному отношению. Ряд авторов (В.А. Евсегнеев и др.) придерживается мнения, согласно которому принудительное изъятие можно считать квазисделкой и формально охарактеризовать отношения как обычную сделку купли-продажи недвижимости. В данном случае акцент делается на том, что земля выкупается по рыночной цене, собственнику возмещается упущенная выгода, обязательна государственная регистрация решения об изъятии, и наконец, результатом выступает переход права собственности и удовлетворение взаимных интересов.

На наш взгляд, данное утверждение отчасти спорно. Собственник лишается законного права владения, использования и распоряжения имуществом против своей воли и часто вынужден приходить ксоглашению в отношении выкупной цены и других условий. Он не обладает той свободой, которой обладают равноправные контрагенты при заключении гражданско-правовой сделки.

Исходя из неизбежного дисбаланса публичных и частных интересов, физические или юридические лица как слабое звено таких отношений нуждаются в специальных мерах защиты. Такими способами защиты являются: правовая регламентация порядка изъятия земельного участка, ограничение публичных интересов путем перечисления исключительных оснований для отчуждения земли и равноценное возмещение собственнику всех понесенных убытков. Полагается, что эти меры должны восстановить нарушенный баланс интересов, однако пробелы и неточности правового регулирования, существующие коллизии между земельным и гражданским законодательством находят свое отражение в судебной практике и свидетельствуют о том, что компенсация нарушенных интересов собственников не всегда осуществляется в полном объеме. 
Прежде всего, это относится к категории принудительного выкупа. Выкуп должен быть предварительным, а его размер - равноценным отчуждаемому имуществу. Под равноценным возмещением понимается цена земельного участка, в которую включаются рыночная стоимость изымаемого участка и находящегося на нем недвижимого имущества, а также все убытки, причиненные собственнику изъятием земельного участка, включая убытки, которые он понесет в связи с досрочным прекращением своих обязательств перед третьими лицами, а также упущенную выгоду ${ }^{4}$.

По соглашению с собственником ему может быть предоставлен взамен участка, изымаемого для государственных или муниципальных нужд, другой земельный участок с зачетом его стоимости в выкупную цену. Но на практике подобное положение не реализуется, поскольку у исполнительных органов государственной власти, субъектов РФ и муниципальных образований возникают сложности с определением земельного участка, который можно было бы предоставить взамен изъятого для государственных или муниципальных нужд. Поэтому, денежная форма возмещения является основной.

Рыночная стоимость земельного участка представляет собой наиболее вероятную цену, по которой объект оценки может быть отчужден на открытом рынке в условиях конкуренции, когда стороны сделки действуют разумно, располагая всей необходимой информацией, а на величине цены сделки не отражаются какие-либо чрезвычайные обстоятельства ${ }^{5}$. Однако в ряде случаев у собственника есть веские основания предполагать, что ценность земли может повыситься в будущем. Насколько оправданы такие предположения закон заранее определить не может. Но собственник земли вправе требовать проверки правильности выплачиваемой ему компенсационной суммы через суд. Исходя из этого можно сделать вывод, что допустима проверка как текущей, так и будущей ценности отчуждаемой земли, если собственник настаивает на этом и обладает доказательствами, что его оценка основана на реальных расчетах (например, заказанный им проект мелиорации обещает определенное повышение доходности земельного участка, а, следовательно, и его ценности).

Закон допускает изъятие не всего земельного участка, а его части. Даже если размеры земельного участка, на который собственник не теряет никаких прав, допустимы в соответствии с действующим законодательством, оставшаяся часть может стать для него мало - или вовсе бездоходной ${ }^{6}$. Закон не предусматривает ситуацию, когда сам собственник требует, чтобы инициатор отчуждения выкупил у него всю его землю, более того, закон вообще не упоминает о возможной бездоходности (или пониженной

4 Постановление Пленума ВАС РФ от 24.03.2005 № 11 О некоторых вопросах, связанных с применением земельного законодательства, Вестник ВАС РФ. 2005 № 5.

5 Федеральный закон от 29.07.1998 № 135-ФЗ Об оценочной деятельности в Российской Федерации, СЗ РФ. 1998 № 31, Ст. 3813.

6 В.А. Евсегнеев, Собственность на землю в фокусе интересов, Журнал российского права 8/2004, С. 69-79. 
доходности) для собственника остающейся у него части земли, и в этом видится его пробел.

Выкуп земельного участка затрагивает интересы не только собственников, но и иных лиц - постоянных пользователей земли, лиц, владеющих землей на праве пожизненного наследуемого владения, а также арендаторов земли и лиц, владеющих землей на праве безвозмездного срочного пользования. В связи с отсутствием у землепользователей, землевладельцев и арендаторов права собственности на земельные участки последние у них не выкупаются, т.е. им не возмещается стоимость изымаемых участков. Однако им должна быть возмещена стоимость принадлежащих на праве собственности зданий, строений и сооружений, расположенных на изымаемом земельном участке, а также причиненных изъятием убытков, включая упущенную выгоду, в полном объеме. Очевидно, что круг лиц, затрагиваемых изъятием земли, более широкий. Это могут быть лица, владеющие землей на праве застройки, на праве оперативного управления чужим имуществом, на праве доверительного управления, совместной деятельности и др. В числе затронутых лиц могут оказаться обладатели сервитутных прав, поскольку они распространяются на выкупаемую землю.

Множественность субъектов затрудняет правовое регулирование возмещения убытков в случае принудительного отчуждения. Очевидно, что перечисление в законе всех лиц, интересы которых затрагиваются изъятием земли, не является необходимым. На наш взгляд, достаточно общего указания на то, что компенсация должна выплачиваться всем владельцам и пользователям земли, имеющим на нее законный титул. Действующий ГК РФ предусматривает гарантии прав при изъятии земельных участков для государственных или муниципальных нужд, но согласно ст. 280 ГК РФ они распространяются лишь на собственников и содержательно не совпадают с гарантиями, предусмотренными в ст. 57 ЗК РФ, согласно которой убытки возмещаются не только собственникам, но и землепользователям, землевладельцам и арендаторам земельных участков. Очевидна неполнота и неточность норм гражданского законодательства по этому вопросу.

Пробелом правового регулирования является отсутствие однозначного ответа на вопрос о том, на какую дату должны рассчитываться убытки, подлежащие возмещению. Процедура изъятия земельного участка - длительный процесс. До истечения года со дня получения собственником уведомления изъятие невозможно без его согласия. За этот срок стоимость изымаемого участка может существенно измениться в силу объективных рыночных условий, а также в результате действий (бездействия) собственника или других лиц в отношении участка. Проблема заключается в том, что в разных нормативно правовых актах содержатся разные правила определения дня расчета выкупной цены.

Содержание ст. 280 ГК РФ позволяет сделать вывод, что выкупная цена земельного участка определяется на день, предшествующий регистрации решения об изъятии 
земельного участка, поскольку риск несения затрат и убытков после этого момента несет собственник. К данным затратам и убыткам ГК РФ прямо относит только те, которые связаны с новым строительством, расширением и реконструкцией зданий и сооружений на земельном участке. Все остальные (например, улучшение, удобрение земель) по смыслу нормы подлежат возмещению.

ЗК РФ устанавливает иные правила. Расходы, понесенные собственниками земельных участков, землепользователями, землевладельцами, арендаторами земельных участков на осуществление застройки земельных участков зданиями капитального типа и проведение других мероприятий, существенно повышающих стоимость земли, после уведомления о предстоящем изъятии, в том числе путем выкупа, земельных участков, возмещению не подлежат. Период совершения данных расходов начинается не со дня регистрации решения об изъятии, а с момента получения уведомления о предстоящем изъятии (ст. 36).

Постановление Пленума ВАС РФ (Высший Арбитражный Суд Российской Федерации) от 24.03.2005 № 11 О некоторых вопросах, связанных с применением земельного законодательства содержит еще один момент определения выкупной цены, который существенно отличается от установленного законом - в случаях, когда собственник не согласен со стоимостью объекта, установленной в решении уполномоченного органа об изъятии земельного участка, или когда выкупная цена в нем не указана, и сторонами после принятия решения об изъятии не достигнуто соглашения о выкупной цене, арбитражный суд определяет стоимость объекта, исходя из его рыночной стоимости на момент рассмотрения спора.

Таким образом, можно выделить три разных подхода к определению дня расчета выкупной цены. Эта неясность лишает собственника необходимой гарантии защиты своих интересов.

Помимо условий выкупа земли интерес представляет сама категория государственные и муниципальные нужды, которой в случае изъятия земельного участка придается большая важность, чем категории частная собственность, что и позволяет лишить физическое или юридическое лицо его законных прав.

Стоит отметить, что легального определения государственных и муниципальных нужд в действующем законодательстве РФ не дано. Можно согласиться с В.А. Евсегнеевым, что это публичные нужды, удовлетворение которых идет на пользу либо всего населения страны, либо жителей муниципального образования или региона7

Основания для изъятия земельного участка из частной собственности должны соответствовать таким критериям, как социальная потребность, общественная необходимость и общественные интересы. В литературе эти критерии охватываются поня-

7 В.А. Евсегнеев, Собственность на землю..., С. 69-79. 
204 | Adam Mickiewicz University Law Review

тием общественная польза $a^{8}$. Это понятие нельзя считать однозначным, так как орган, инициирующий отчуждение, может выступать в отношении имущества и как субъект, наделенный публичными полномочиями и своей деятельностью в отношении участка приносящий пользу всему населению, и как обычный собственник, извлекающий из земли доход в своих интересах. Поэтому понятие государственные и муниципальные нужды может выражать как публичные, так и частноправовые потребности. Кроме того, нет серьезных препятствий тому, чтобы изъятый для государственных или муниципальных нужд земельный участок мог использоваться другими частными лицами при условии удовлетворения публичных нужд.

На практике причиной изъятия земельных участков является не только строительство конкретных объектов электроэнергетики или газового хозяйства, перечень которых дан в ЗК РФ, но и такие многозначные и неопределенные по объему и содержанию основания, как реконструкция города, комплексная реконструкция, застройка муниципального образования и т.п. Для того чтобы избежать случаев злоупотребления публичными органами своих полномочий, в отношении каждого конкретного решения об изъятии земельного участка следует учитывать характер, функциональную направленность, размер объекта и другие обстоятельства.

Таким образом, перед российским законодателем стоит актуальная задача более детально разработать положения, касающиеся изъятия земельных участков для государственных или муниципальных нужд, привести в соответствие нормы разной отраслевой принадлежности. В современных условиях любое правовое ограничение прав и свобод человека требует подробной правовой регламентации, отсутствия пробелов и неточностей в законодательстве.

В заключение стоит отметить, что институт принудительного изъятия земельных участков для государственных и муниципальных нужд предусмотрен законодательством многих государств, допуская право государства на принудительное прекращение права собственности на землю. Общим для всех правовых систем является использование таких фундаментальных принципов, как ограничение целей изъятия государственными и муниципальными нуждами, принцип справедливой компенсации стоимости земельного участка. Однако, учитывая все гарантии и меры, восстанавливающие баланс публичных и частных интересов, право частной собственности на землю ограничено общественными интересами и потребностями социального характера, т.е. очевиден отказ от абсолютного характера права собственности и его полной неприкосновенности.

8 У. Маттеи, Е.А. Суханов, Основные положения права собственности, Москва 1999, C. $187-189$. 


\section{Биографическая аннотация:}

Инна Ефремова - Иркутский государственный университет, Юридический институт, отделение международного права. Научные интересы: гражданское право, международное частное право, международный коммерческий арбитраж, транспортные обязательства, договор международной перевозки.

\section{SUMMARY}

\section{Compulsory purchase of the land in the public interest as a form of the property right}

\section{limitation}

The study aims at an evaluation of the compulsory purchase of the land in the public interest in regards to the article 35 of the Constitution of the Russian Federation. The author present the compulsory purchase in the public interest, including land, as a form of the property right limitation, that should fulfil the selected, established law procedures.

KEYwORDS: compulsory purchase, land property, public interest 
